\title{
Beta cells preferentially exchange cationic molecules via connexin 36 gap junction channels
}

\author{
E. Charpantier $\cdot$ J. Cancela $\cdot$ P. Meda
}

Received: 11 May 2007 / Accepted: 19 July 2007 / Published online: 8 September 2007

(C) Springer-Verlag 2007

\begin{abstract}
Aims/hypothesis Pancreatic beta cells are connected by gap junction channels made of connexin 36 (Cx36), which permit intercellular exchanges of current-carrying ions (ionic coupling) and other molecules (metabolic coupling). Previous studies have suggested that ionic coupling may extend to larger regions of pancreatic islets than metabolic coupling. The aim of the present study was to investigate whether this apparent discrepancy reflects a difference in the sensitivity of the techniques used to evaluate beta cell communication or a specific characteristic of the $\mathrm{Cx} 36$ channels themselves.

Methods We microinjected several gap junction tracers, differing in size and charge, into individual insulin-producing cells and evaluated their intercellular exchange either within intact islets of control, knockout and transgenic mice featuring beta cells with various levels of Cx36, or in cultures of wildtype and Cx36-transfected MIN6 cells.

Results We found that (1) $\mathrm{Cx} 36$ channels favour the exchange of cations and larger positively charged molecules between beta cells at the expense of anionic molecules; (2) this exchange occurs across sizable portions of pancreatic islets; and (3) during glibenclamide (known as glyburide in the USA and Canada) stimulation beta cell coupling increases to an extent that varies for different gap junction-permeant molecules.
\end{abstract}

Electronic supplementary material The online version of this article (doi:10.1007/s00125-007-0807-9) contains supplementary material, which is available to authorised users.

E. Charpantier $\cdot$ J. Cancela $\cdot$ P. Meda $(\bowtie)$

Department of Cell Physiology and Metabolism,

University of Geneva, C.M.U.,

1 rue Michel Servet,

1211 Geneva 4, Switzerland

e-mail: Paolo.Meda@medecine.unige.ch
Conclusions/interpretation The data show that beta cells are extensively coupled within pancreatic islets via exchanges of mostly positively charged molecules across $\mathrm{Cx} 36$ channels. These exchanges selectively increase during stimulation of insulin secretion. The identification of this permselectivity is expected to facilitate the identification of endogenous permeant molecules and of the mechanism whereby $\mathrm{Cx} 36$ signalling significantly contributes to the modulation of insulin secretion.

Keywords $\mathrm{Ca}^{2+}$. Cell coupling · Connexins .

Gap junctions · Islet cells · Ionic exchanges ·

Intercellular communication - Molecular exchanges .

Signalling $\cdot$ Synchronisation

$\begin{array}{ll}\text { Abbreviations } \\ \text { CF } & \text { 6-carboxyfluorescein } \\ \text { Cx32 } & \text { connexin } 32 \\ \text { Cx36 } & \text { connexin } 36 \\ \text { Cx43 } & \text { connexin } 43 \\ \text { EB } & \text { ethidium bromide } \\ \text { KO } & \text { knockout } \\ \text { LY } & \text { Lucifer Yellow } \\ \text { PI } & \text { propidium iodide } \\ \text { RIP } & \text { rat insulin gene promoter }\end{array}$

\section{Introduction}

Among the many membrane channels that contribute to control insulin secretion [1-3], those made by connexin proteins at gap junctions [4-6] are attracting increasing interest, since they are implicated in the ionic and metabolic coupling of beta cells, i.e. in the cell-to-cell exchanges of 
current-carrying ions and other small cytosolic molecules [7-15]. Recent evidence has shown that these exchanges ensure the synchronisation and recruitment of beta cells during insulin secretion [9, 10, 15-23]. Thus, deletion of connexin 36 (Cx36), the only protein so far shown to form beta cell gap junctions in vivo [24, 25], resulted in loss of these structures [21] and in the uncoupling of beta cells [21, 22]. In turn, these changes were associated with alterations in the synchronisation of glucose-induced calcium waves, basal insulin release, pulsatile pattern of insulin secretion, off response of glucose-stimulated islets and other mechanisms of beta cell to beta cell communication $[21,22,26$, 27]. To understand how loss of $\mathrm{Cx} 36$ leads to these changes, it is necessary to identify the signals that are transferred by $\mathrm{Cx} 36$ channels, and to evaluate the extent of such a transfer in the environment of intact pancreatic islets. Previous electrophysiological studies have shown that ionic coupling extends to large regions of the islets, as judged by both the electrical synchronisation of beta cells and the intercellular diffusion of electrotonic currents [5, 7, 10, 22]. In contrast, experiments testing the cell exchange of radioactive precursors [11] and exogenous tracers $[8,12$, 18] have suggested that metabolic coupling within pancreatic islets may be restricted to territories comprising only a few beta cells $[8,11,15]$. This apparent discrepancy may reflect the different sensitivity of the techniques used to evaluate coupling $[28,29]$, the specific characteristics of the Cx36 channels $[4,13,30,31]$ and/or an influence of the islet setting that could modulate these channels $[5,10,13$, 23, 32].

We tackled this question by evaluating the intercellular exchange of various tracers of different size and charge following microinjection into individual beta cells of isolated mouse islets or cultures of MIN6 cells.

\section{Methods}

Cell lines Wild-type human cervix carcinoma HeLa cells (American Type Culture Collection-LGC Promochem, Teddington, Middlesex, UK) and stable clones of HeLa cells transfected with either Cx36 [31] or connexin $43(\mathrm{Cx} 43)$ [33] were cultured in DMEM containing $25 \mathrm{mmol} / \mathrm{l}$ glucose and $10 \%$ calf serum. Wild-type mouse insulinoma MIN6 cells [34] and a stable clone of these cells that had been depleted of Cx36 [26, 35] were also cultured in DMEM medium containing $15 \%$ heat-inactivated fetal calf serum and $70 \mu \mathrm{mol} / 1 \beta$-mercaptoethanol. Cells were kept at $37^{\circ} \mathrm{C}$ in a humidified incubator, gassed with air and $6 \% \mathrm{CO}_{2}$, fed at 3 day intervals and passed once a week.

Mice and rats Adult mice of the C57/B16 (Charles River Laboratories, Lyon, France), KO-Cx36 [36] and rat insulin gene promoter (RIP)-connexin $32(\mathrm{Cx} 32)$ strains [17] were used to isolate islets of Langerhans. All transgenic mice were crossed with C57/B16 mice for a minimum of five generations. Normal adult rats were of the OFA strain (IFFA-Credo, Lyon, France). Maintenance and anaesthesia (5\% isoflurane) of mice and rats were in accordance with the regulations of our institutional and state committees on animal welfare.

In some experiments, control mice received an i.p. injection of $2 \mathrm{mg} / \mathrm{kg}$ glibenclamide (known as glyburide in the USA and Canada; Sanofi-Aventis, Frankfurt, Germany) every $12 \mathrm{~h}[12,37,38]$. Islets were isolated $24 \mathrm{~h}$ after the first injection.

Pancreatic islets Islets of Langerhans were isolated by collagenase digestion, as previously described [17]. For microinjection, the freshly isolated islets were attached to Sylgard- and poly-L-lysine-coated dishes [17] and kept in Hanks' balanced salt solution $(\mathrm{NaCl} 138 \mathrm{mmol} / \mathrm{l}, \mathrm{KCl}$ $5 \mathrm{mmol} / 1, \quad \mathrm{CaCl}_{2} \cdot 2 \mathrm{H}_{2} \mathrm{O} 1.25 \mathrm{mmol} / \mathrm{l}, \mathrm{MgSO}_{4} \cdot 7 \mathrm{H}_{2} \mathrm{O}$ $0.8 \mathrm{mmol} / 1, \quad \mathrm{Na}_{2} \mathrm{HPO}_{4} \cdot 2 \mathrm{H}_{2} \mathrm{O} 0.34 \mathrm{mmol} / 1, \mathrm{KH}_{2} \mathrm{PO}_{4}$ $0.35 \mathrm{mmol} / \mathrm{l}, \mathrm{NaHCO}_{3} 4.2 \mathrm{mmol} / \mathrm{l}$, glucose $2.8 \mathrm{mmol} / \mathrm{l}$ and HEPES $10 \mathrm{mmol} / \mathrm{l}, \mathrm{pH} 7.25$ ) at room temperature and under a humidified atmosphere. All islets were tested within the next $8 \mathrm{~h}$, during which time the extent of coupling remained stable.

Tracer microinjection Cell monolayers and isolated islets were transferred on to the heated $\left(37^{\circ} \mathrm{C}\right)$ stage of either an inverted (cultures) or standard Zeiss microscope (islets). Individual cells were microinjected for $10 \mathrm{~min}$, using glass pipettes pulled to a resistance of 50-60 $\mathrm{M} \Omega$, as assessed in $150 \mathrm{mmol} / 1 \mathrm{LiCl}$. The tip of the pipette contained the tracer under study, whereas the shaft was filled with $3 \mathrm{~mol} / \mathrm{l} \mathrm{LiCl}$ [28]. The following tracers were compared: $4 \%$ Lucifer Yellow (LY; net charge -2 ; mol. wt 457 ; size $12.6 \times 14 \times$ $5.5 \AA$ ); $4 \%$ ethidium bromide (EB; net charge +1 ; mol. wt 394; size $11.6 \times 9.3 \times 4.3 \AA$ ); $1 \%$ 6-carboxyfluorescein $(\mathrm{CF}$; net charge -2 ; mol. wt 376 ; size $12.6 \times 12.7 \times 8.5 \AA) ; 1 \%$ propidium iodide (PI; net charge +1 ; mol. wt 661 ; size $12.9 \times 9.3 \times 4.5 \AA)$. All tracers were from Sigma-Aldrich $(\mathrm{St}$ Louis, MO, USA), except CF, which was from Eastman Kodak (Rochester, NY, USA), and were dissolved in $150 \mathrm{mmol} / 1 \mathrm{LiCl}$ buffered to $\mathrm{pH} 7.2$ with $10 \mathrm{mmol} / 1$ HEPES. Following cell penetration, each tracer was iontophoretically injected for $10 \mathrm{~min}$, by applying square pulses of $0.1 \mathrm{nA}$ amplitude, $900 \mathrm{~ms}$ duration and $0.5 \mathrm{~Hz}$ frequency $[12,28]$. Pulses were positive for injection of $\mathrm{EB}$ and PI, and negative for injection of LY and CF. In some experiments, individual islet cells were simultaneously microinjected with LY and EB, by mixing the two tracers in the same micropipette and alternating the polarity of the pulses at each injection cycle. In all cases, the injected field 
was recorded with either a 3CCD C5810 digital camera (Hamamatsu Photonics, Solothurn, Switzerland) or an Axiocam camera (Carl Zeiss SMT, Oberkochen, Germany), using fluorescence settings for FITC or rhodamine and an exposure time that was constant for each dye $[28,39]$.

Fluorescence quenching Three-day cultures of MIN6 cells were loaded with $4 \mu \mathrm{mol} / 1$ calcein-AM (net charge -4 ; mol. wt 623 ; size $13.88 \times 13.79 \times 4.29 \AA$ ) in DMEM for 20 min at room temperature [39]. After rinsing with DMEM, individual cells were microinjected with $10 \mathrm{mmol} / 1 \mathrm{MnCl}_{2}$ in $150 \mathrm{mmol} / \mathrm{l} \mathrm{LiCl}$. The intercellular exchange of $\mathrm{Mn}^{2+}$ was monitored under epifluorescence, due to the calcein quenching it induced [40]. Each field was photographed before each microinjection and $10 \mathrm{~min}$ later.

Histology Some microinjected islets were fixed for $15 \mathrm{~h}$ in $4 \%(\mathrm{w} / \mathrm{v})$ paraformaldehyde in $0.1 \mathrm{~mol} / 1$ phosphate buffer, processed for either paraffin or epon embedding, sectioned at 1 to $5 \mu \mathrm{m}$ thickness, immunostained for insulin and photographed as described [17, 41].

Evaluation of coupling Cell coupling was defined as the tracer diffusion from the injected cell into at least one of its neighbour cells. Cell uncoupling was defined as the persisting presence of the tracer in only the microinjected cell.

To evaluate coupling extent in cultures, the phasecontrast and fluorescence images of each injected field were superimposed using Adobe Photoshop software and the number of cells labelled by a tracer directly counted.
In the calcein quenching experiments, the same approach was used to score the number of cells that had lost fluorescence.

In the three dimensional islets, a direct counting of the coupled cells was rarely feasible. Thus, coupling was evaluated by measuring with Image J software ( http://rsb. info.nih.gov/ij/, last accessed in August 2007 ) [42] the area labelled by each tracer, on photographs of the intact islets $[12,19,21,28]$. The number of coupled cells was then estimated by dividing this area by that of individual beta cells, as determined in the uncoupled islets of KO-Cx36 mice. To validate this procedure and to identify the type of coupled cells by immunolabelling, some microinjected islets were fixed, plastic-embedded and serially sectioned $[12,19,21,28]$, in order to reconstruct in three dimensions the territories made up of coupled islet cells [Electronic supplementary material (ESM) Video clips 1 and 2]. This approach is limited by the loss of some EB and LY from the fixed cells and is quite time-consuming. Therefore it could not be used to accurately compare the sizable number of islets that had to be microinjected.

In cultures and islets, the rank order of coupled cells was given by the position of the tracer-labelled (or fluorescencequenched) cells, relative to that of the microinjected cell $[17,33,39,41]$. Cells contacting the injected cells were referred to as first order. Cells at a one cell distance from the injected cell were referred to as second order and so on. Quantitative data were compared by analysis of variance and ad hoc $t$ tests, as provided by SPSS software (SPSS, Chicago, IL, USA).
Fig. $1 \mathrm{Cx} 36$ and $\mathrm{Cx} 43$ channels favour the exchange between HeLa cells of cationic and anionic molecules, respectively. a HeLa cells stably transfected for Cx36 exchanged the positively charged EB more than the negatively charged LY and CF. b Cells expressing $\mathrm{Cx} 43$ showed an opposite pattern, i.e. exchanged LY and CF to a much greater degree than either EB or PI. Bar $100 \mu \mathrm{m}$. c Numbers of cells (wild-type, solid bars; Cx36-transfected, open bars; Cx43-transfected, grey bars) labelled by a gap junction tracer after microinjection into one cell. Data are presented as means \pm SEM; the values above the bars represent the number of microinjections. ${ }^{*} p<0.05$, ${ }^{\dagger} p<0.005,{ }^{\star} p<0.0001$ vs the same tracer in wild-type cells

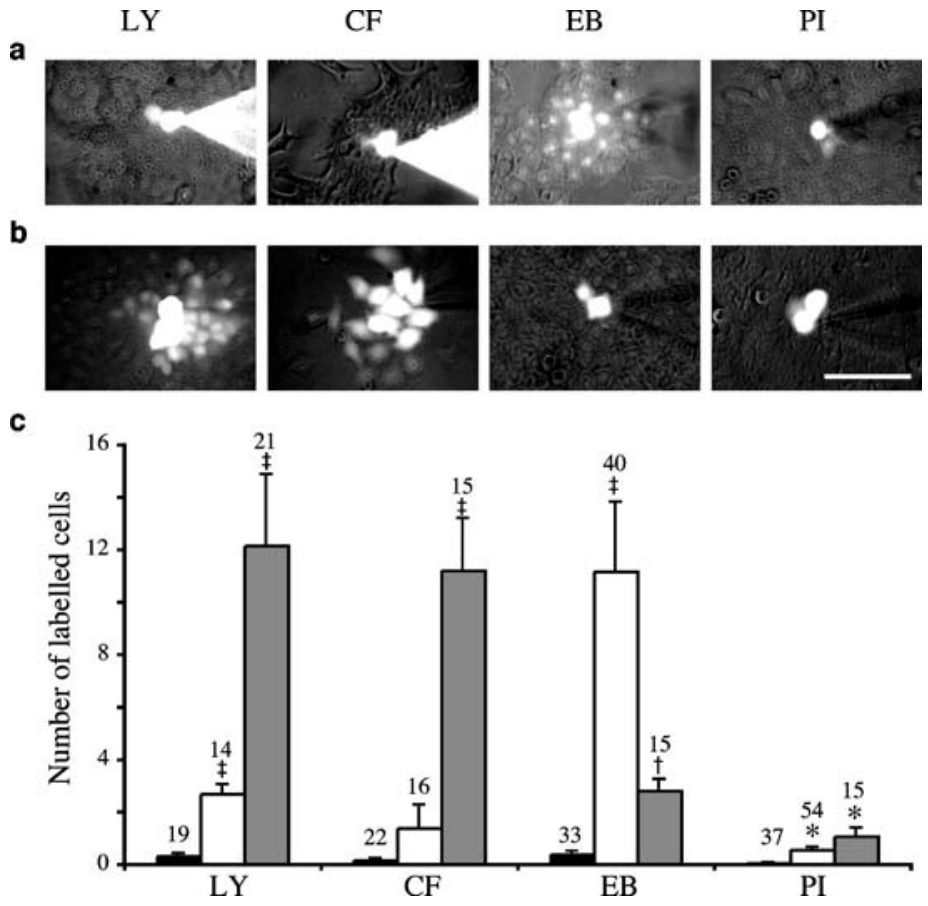


Table 1 Percentage of injections resulting in coupling of HeLa cells and rank order of this event

\begin{tabular}{|c|c|c|c|c|c|c|c|c|}
\hline \multirow[t]{2}{*}{ Dye } & \multirow[t]{2}{*}{$\mathrm{HeLa}$} & \multicolumn{7}{|c|}{ Coupling rank order } \\
\hline & & 0 & 1 & 2 & 3 & 4 & 5 & $n$ \\
\hline \multirow[t]{3}{*}{ LY } & wt & 94.7 & 5.3 & 0 & 0 & 0 & 0 & 19 \\
\hline & $\mathrm{Cx} 36$ & 7.1 & 92.9 & 7.1 & 0 & 0 & 0 & 14 \\
\hline & $\mathrm{Cx} 43$ & 10.5 & 89.5 & 57.9 & 42.1 & 26.3 & 15.8 & 19 \\
\hline \multirow[t]{3}{*}{$\mathrm{CF}$} & wt & 100 & 0 & 0 & 0 & 0 & 0 & 22 \\
\hline & $\mathrm{Cx} 36$ & 50 & 50 & 12.5 & 0 & 0 & 0 & 16 \\
\hline & $\mathrm{Cx} 43$ & 13.3 & 86.7 & 66.7 & 33.3 & 20 & 6.7 & 15 \\
\hline \multirow[t]{3}{*}{ EB } & wt & 100 & 0 & 0 & 0 & 0 & 0 & 33 \\
\hline & $\mathrm{Cx} 36$ & 27.5 & 72.5 & 52.5 & 32.5 & 17.5 & 12.5 & 40 \\
\hline & $\mathrm{Cx} 43$ & 13.3 & 86.7 & 20 & 0 & 0 & 0 & 15 \\
\hline \multirow[t]{3}{*}{ PI } & wt & 100 & 0 & 0 & 0 & 0 & 0 & 37 \\
\hline & Cx36 & 59.3 & 40.7 & 3.7 & 0 & 0 & 0 & 54 \\
\hline & $\mathrm{Cx} 43$ & 46.7 & 53.3 & 6.7 & 0 & 0 & 0 & 15 \\
\hline
\end{tabular}

$n$ Number of injections; $w t$ wild-type

\section{Results}

Coupling of HeLa cells Since HeLa cells lack wild-type connexins and can be transfected to express individual isoforms of these proteins [31, 33], they were used to validate the tracer injection experiments to be performed with islets. Injection of each of four different tracers into wild-type HeLa cells consistently resulted in uncoupling (Fig. 1c, Table 1). In clones transfected for either $\mathrm{Cx} 43$ or Cx36, coupling was observed between HeLa cells in a sizable proportion of the injections (Fig. 1a-c, Table 1). The extent of this coupling varied according to the tracer used and the connexin expressed. Thus, coupling was minimal when assessed by PI injection and significantly larger when evaluated with LY, CF or EB (Fig. 1a-c, Table 1). The negatively charged LY and CF revealed a much greater coupling than the positively charged EB in HeLa cells expressing Cx43 (Fig. 1b,c, Table 1), whereas the reverse was observed in HeLa cells expressing Cx36 (Fig. 1a,c, Table 1). Strikingly, however, these cells markedly discriminate between the positively charged EB
Fig. 2 Coupling of primary islet cells depends on Cx36 and is mostly due to cationic molecules. a In islets isolated from wild-type mice, cells poorly exchanged LY and CF, but exchanged EB and PI to a greater degree. Note that LY and CF accumulate in the cytosol, whereas EB and PI mostly stain the nucleus, resulting in a spotted labelling of the most distant coupled cells (arrowheads). Bar, $100 \mu \mathrm{m}$. b In islets of KO $\mathrm{C} \times 36^{-1-}$ mice, which lack $\mathrm{Cx} 36$, the four tracers revealed cell uncoupling. c Area labelled by each tracer in islets of wild-type (solid bars) and $\mathrm{KO}-\mathrm{Cx} 36^{-/}$ mice (open bars). Data are presented as means \pm SEM; the values above the bars represent the number of microinjections. ${ }^{*} p<0.05,{ }^{\star} p<0.0001$ vs wildtype value for the same tracer; $\S_{p}<0.05, "{ }_{p}<0.005$ vs the LY value in wild-type islets a

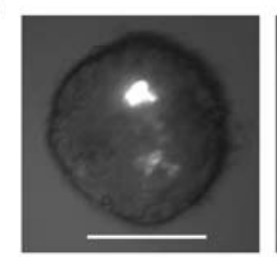

CF

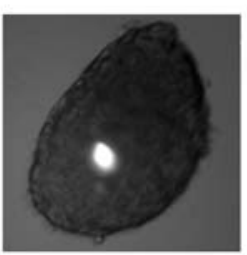

EB

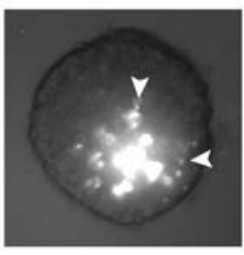

b
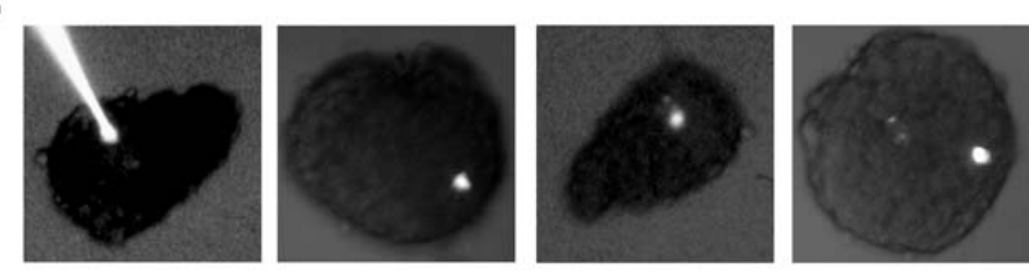

C

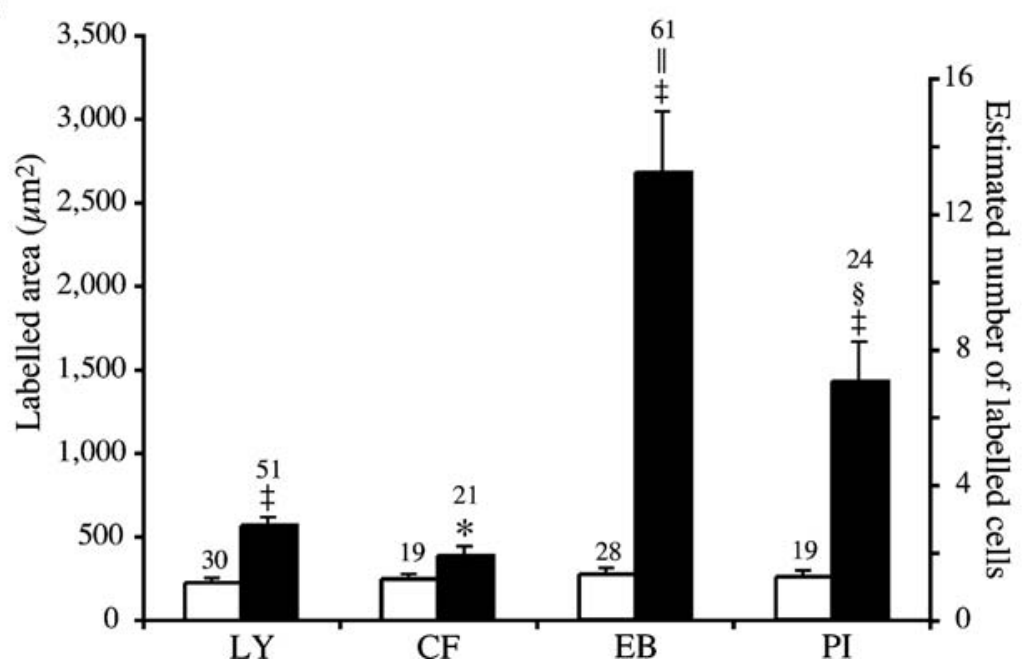


Fig. 3 Positively and negatively charged tracers reveal a different extent of beta cell coupling. a-c Individual cells of a control mouse islet (a shows phasecontrast view) were sequentially microinjected with LY (b) and EB (c). LY revealed either apparently uncoupled cells $\left(^{*}\right)$ or cells coupled to first-rank neighbours (arrowheads) (b). In contrast, after a cell was injected with EB (arrow), territories of coupled cells extending up to the fifth rank order were seen (c). The outline of the islet is shown by the dotted line. Bar (c), $20 \mu \mathrm{m}$. d-f Immunostaining for insulin (d) of a control mouse islet microinjected with EB (e) revealed that most coupled cells were insulincontaining cells (f). f Panels d and e merged. Bar (e), $20 \mu \mathrm{m}$. g-i Individual cells were simultaneously microinjected with both LY (g) and EB (h). The latter tracer revealed a much larger extent of coupling than the former one. i Panels $\mathbf{g}$ and h merged, which are colourcoded versions of original black and white pictures. Bar (i),

$100 \mu \mathrm{m}$. j Consecutive sections (numbered) of a rat islet microinjected with both EB and LY. A larger diffusion of the former tracer can be seen. Bar, $20 \mu \mathrm{m}$
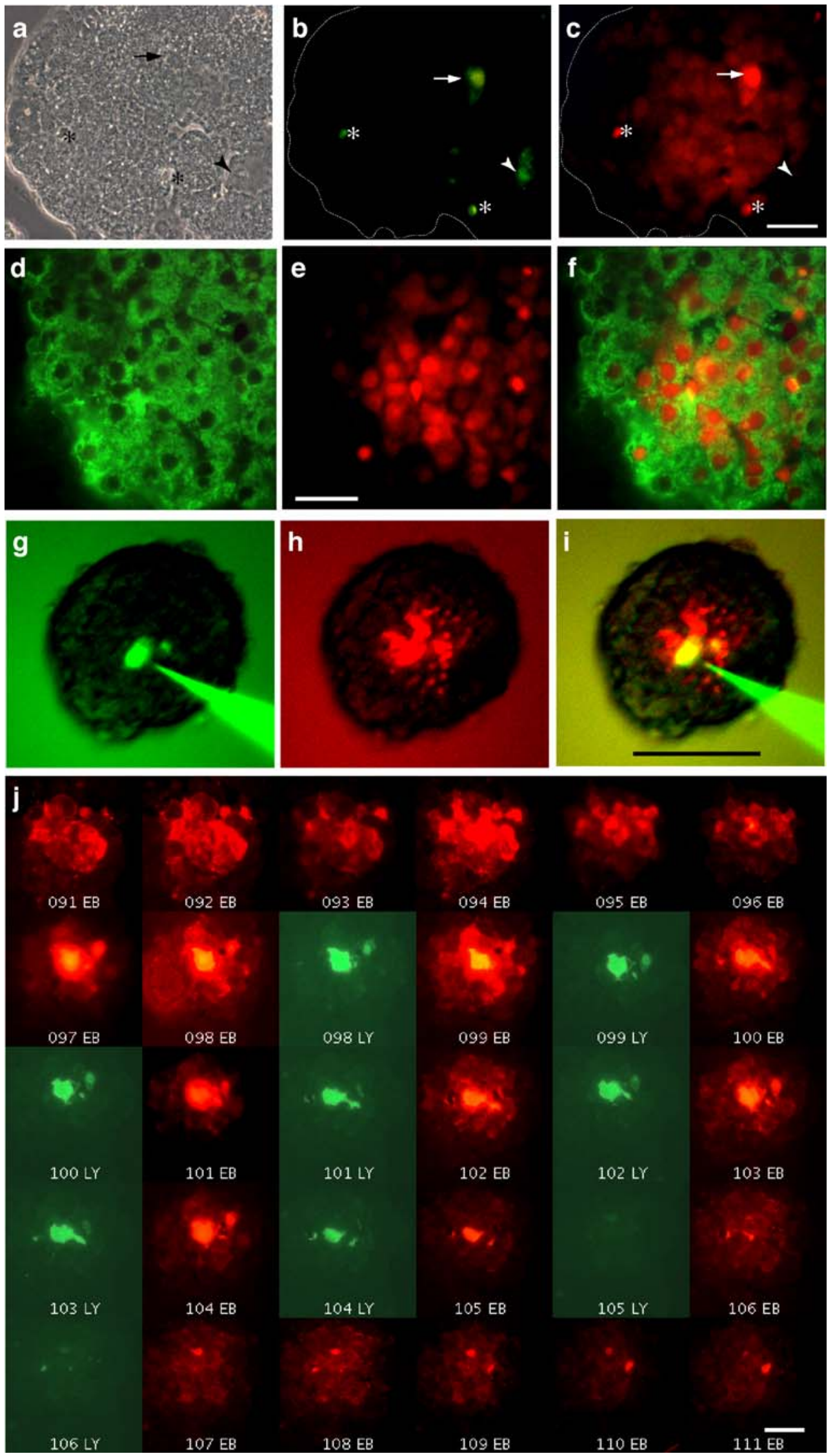
and PI, the latter, which easily permeates the $\mathrm{C} \times 36$ channels of beta (Figs. 2, 3, and 4) and MIN6 cells (Fig. 5), being only minimally exchanged between Cx36-coupled HeLa cells (Fig. 1). These findings document that the cell-to-cell transfer of the four tracers we selected depends on connexin expression and that $\mathrm{Cx} 36$ channels favour the intercellular exchange of selected cationic molecules.

Coupling of beta cells After microinjection into individual beta cells of islets isolated from control mice (C57/B16 and wild-type mice of the different knockout (KO) and transgenic lines mentioned below), the same four tracers showed frequent coupling (Fig. 2). The extension of this coupling was limited for LY ( $3 \pm 1$ coupled cells in $82.4 \%$ of 51 injections) and CF ( $2 \pm 1$ cells in $76.2 \%$ of 21 injections), sizable for PI ( $7 \pm 2$ cells in $87.5 \%$ of 24 injections) and much larger for EB ( $14 \pm 2$ cells in $90.2 \%$ of 61 injections;

LY

a

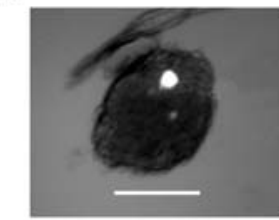

b

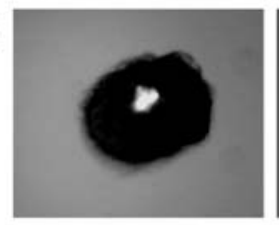

C

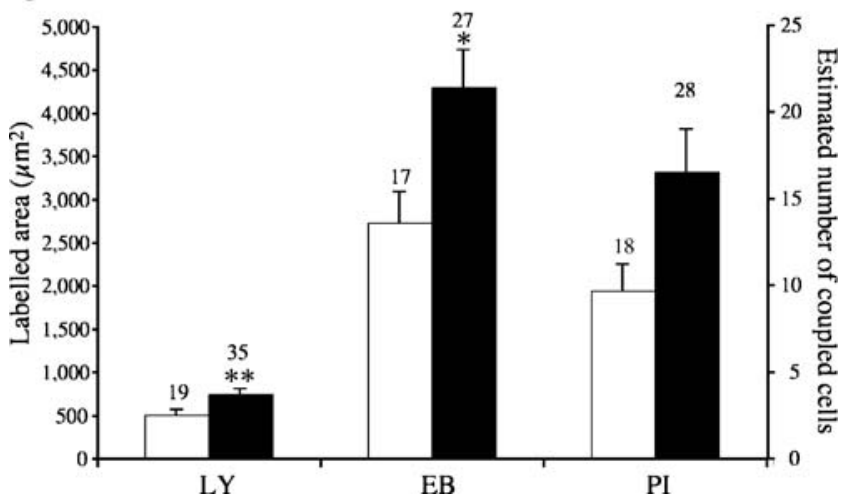

Fig. 4 Beta cell coupling changes selectively after glibenclamide stimulation. a In untreated islets of wild-type mice, cells poorly exchanged LY, but extensively exchanged EB and PI. Bar, $100 \mu \mathrm{m}$. Note that LY accumulates in the cytosol, whereas EB and PI mostly stain the nucleus, resulting in spotted labelling of the most distant coupled cells (arrowheads). b After $24 \mathrm{~h}$ of glibenclamide treatment, the three tracers extended to larger areas of the microinjected islets. c Area labelled by each tracer in islets of control (open bars) and glibenclamide-stimulated (solid bars) mice. Data are presented as means \pm SEM; the values above the bars represent the number of microinjections. $* p<0.05, * * p<0.01$ vs the value for the same tracer in non-stimulated islets
Fig. 2a). Histology showed that the number of coupled cells was much higher after injection of EB than LY (Fig. 3b,c) and that these were mostly insulin-containing beta cells (Fig. 3d-f). In islets that were simultaneously microinjected with LY and EB (Fig. 3g-i), we further observed that a number of cells that appeared to be coupled to only a few neighbours as indicated by LY transfer $(2 \pm 1$ cells in $89 \%$ of 18 injections) were actually coupled to more cells when assessed with EB ( $6 \pm 2$ cells in $93 \%$ of 15 injections). Also, some of the cells that were scored as uncoupled with the former dye, were shown to be coupled when evaluated with the latter one. Some islet cells were found uncoupled with both LY and EB injection (data not shown). Comparable differences were seen in control rat islets (Fig. 3j), where the reconstruction of LY and EB labelling showed that the two tracers diffused in a non-radial manner to outline territories of complex geometry, which also comprised some uncoupled cells (Fig. 3j, ESM Video clips 1 and 2).

To determine whether the intercellular transfer of the four tracers mentioned above occurred via Cx36 channels, we repeated the experiments in islets of the $\mathrm{KO} \mathrm{Cx} 36$ strain [21, 22, 36]. Wild-type $\mathrm{KO} \mathrm{Cx} 36^{+/+}$mice, which express normal levels of $\mathrm{Cx} 36$ [21], showed limited islet cell coupling when tested with either LY or CF and a significantly larger coupling when tested with either EB or PI (Fig. 2a,c). In contrast, homozygous $\mathrm{KO} \mathrm{Cx} 36^{-1-}$ littermates, which lack Cx36 [21], consistently showed uncoupling, irrespective of the tracer used (Fig. 2b,c).

To assess whether the cationic selectivity of beta cell coupling was dependent on Cx36, we studied islets of the transgenic RIP-Cx32 mouse, whose beta cells ectopically express Cx32 in addition to native Cx36 [17]. These two connexins form junctional channels with rather different conductances and permeabilities [4, 33]. Islet cells of wildtype RIP-Cx32 mice, which express normal levels of Cx36 and no Cx32 [17], showed a much smaller coupling when tested with LY than when tested with either EB or PI (not shown), similar to results observed with other control mice. In contrast, islet cells of homozygous RIP-Cx $32^{+/+}$littermates, which co-express $\mathrm{Cx} 32$ and $\mathrm{Cx} 36$ [17], showed a significant $(p<0.001)$ increase in coupling, as evaluated by LY microinjection ( $3 \pm 1$ coupled cells in 13 control injections vs $17 \pm 4$ coupled cells in 22 injections in homozygous littermates). The intercellular transfer of PI was also larger $(p<0.004)$ in mice expressing Cx32 $\left(5,262 \pm 804 \mu \mathrm{m}^{2}, n=12\right)$ than in their wildtype littermates $\left(2,467 \pm 477 \mu \mathrm{m}^{2}, n=13\right)$, whereas that of EB increased less $(p<0.11)$ from $2,762 \pm 434 \mu \mathrm{m}^{2}(n=15$ controls $)$ to $4,139 \pm 759 \mu \mathrm{m}^{2}(n=22)$ in mice co-expressing Cx32 and Cx36. These findings show that the selective cell-to-cell transfer of cationic tracers observed in control islets depends on the expression of $\mathrm{Cx} 36$ channels. They further indicate 
Fig. 5 MIN6 cells, like primary beta cells, are coupled by $\mathrm{Cx} 36$. a Wild-type MIN6 cells, which express Cx36, exchanged EB and PI to a greater degree than LY and CF. b In an antisensetransfected clone of MIN6 cells (Min6-AS-Cx36) that no longer expresses Cx36, limited intercellular exchange of these tracers was observed. Bar, $100 \mu \mathrm{m}$. c Number of wild-type (solid bars) and Cx36-antisense cells (open bars) labelled by a tracer, after microinjection into one cell. Data are presented as means \pm SEM; the values above the bars represent the number of microinjections. ${ }^{*} p<0.05$, ${ }^{\ddagger} p<0.0001$ vs the value for the same tracer in $\mathrm{Cx} 36$-antisense cells
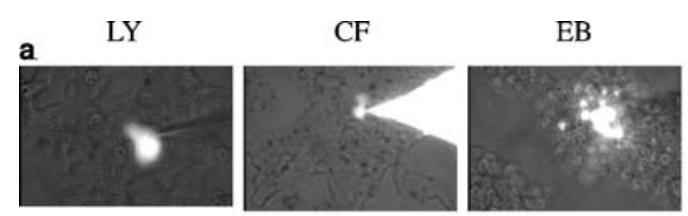

PI
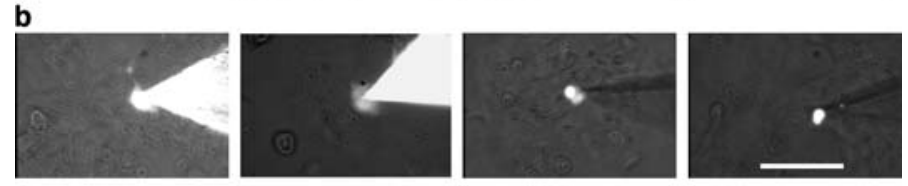

C

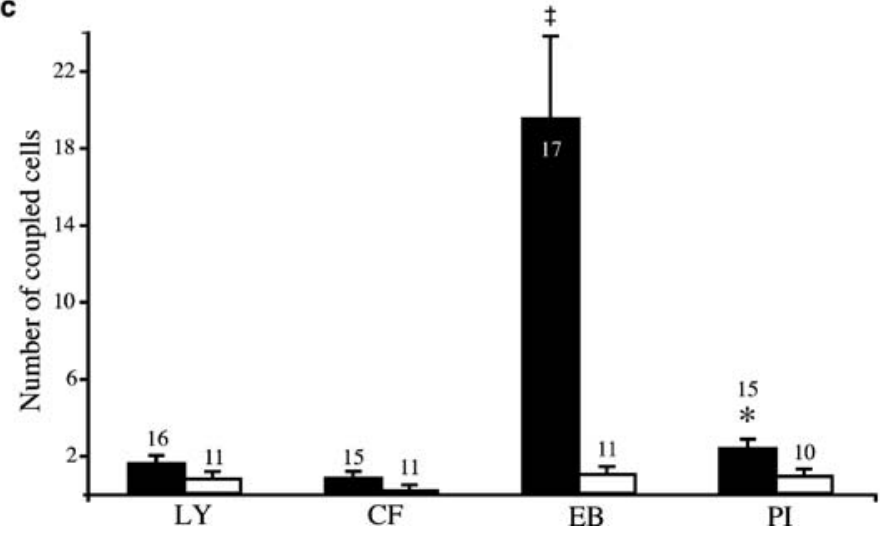

that, as in another model [17, 39], this selectivity is altered in beta cells forced to express another connexin isoform.

Beta cell coupling selectively increases after glibenclamide stimulation To assess whether beta cell coupling changes as a function of insulin secretion, we treated control mice with glibenclamide for 1 day, in conditions known to stimulate beta cells and to enhance the size of their gap junction plaques [12, 37, 38]. During sulfonylurea stimulation, the size of the coupling territories delineated by EB and PI was much larger $(p<0.001)$ than that delineated by LY (Fig. 4), as seen in non-stimulated controls. However, relative to the size of the coupling territory evaluated in non-stimulated islets, that observed after glibenclamide treatment was differently modulated for different tracers, irrespective of their electrical charge. Thus, coupling increased on average by $46 \%(p=0.009), 55 \%(p=0.02)$ and $67 \%(p=0.06)$, as evaluated by LY, EB and PI injection, respectively (Fig. 4). The data indicate that the number and/or function of $\mathrm{Cx} 36$ channels is increased during glibenclamide stimulation, resulting in a different increase in beta cell coupling for different cationic and anionic molecules.

Coupling of Min6 cells To further test the cationic permselectivity of Cx36 channels, we investigated MIN6 cells, which natively express Cx36 [26, 35]. Wild-type cells featured a minimal coupling when assessed with LY and $\mathrm{CF}$, but a larger and more frequent coupling when tested with EB and PI (Fig. 5a,c, Table 2). The dependence of this event on Cx36 was shown using a stable clone of MIN6 cells, which expresses minimal levels of $\mathrm{Cx} 36$ at the membrane, as a result of antisense transfection [26, 35]. In these cells, little coupling was observed, irrespective of the tracer used (Fig. 5b,c, Table 2).

To determine whether the intercellular exchange of cationic molecules was dependent on their size, we investigated MIN6 cells that had been loaded with calcein-AM, using a fluorescence quenching strategy [40]. We observed that wild-type cells featured a consistent progression of fluorescence quenching from the microinjected cell into adjacent neighbours (Fig. 6a,b,e) and that the extent of this coupling was intermediate between that

Table 2 Percentage of injections resulting in coupling of MIN6 cells and rank order of this event

\begin{tabular}{lllllllll}
\hline \multirow{2}{*}{ Dye } & \multirow{2}{*}{ MIN6 } & \multicolumn{7}{l}{ Coupling rank order } \\
\cline { 3 - 8 } & & 0 & 1 & 2 & 3 & 4 & 5 & $n$ \\
\hline LY & wt & 31.2 & 68.8 & 18.8 & 0 & 0 & 0 & 16 \\
& AS-Cx36 & 70 & 30 & 0 & 0 & 0 & 0 & 10 \\
CF & wt & 53.3 & 46.7 & 6.7 & 0 & 0 & 0 & 15 \\
& AS-Cx36 & 72.7 & 27.3 & 0 & 0 & 0 & 0 & 11 \\
EB & wt & 23.5 & 76.5 & 70.6 & 64.7 & 52.9 & 29.4 & 17 \\
& AS-Cx36 & 27.3 & 72.7 & 18.2 & 0 & 0 & 0 & 11 \\
PI & wt & 20 & 80 & 26.7 & 6.7 & 0 & 0 & 15 \\
& AS-Cx36 & 70 & 30 & 0 & 0 & 0 & 0 & 10 \\
Mn ${ }^{2+}$ & wt & 0 & 100 & 72.7 & 9.1 & 9.1 & 9.1 & 11 \\
& AS-Cx36 & 58.3 & 41.7 & 0 & 0 & 0 & 0 & 12 \\
\hline
\end{tabular}

$n$ Number of injections; $w t$ wild-type 

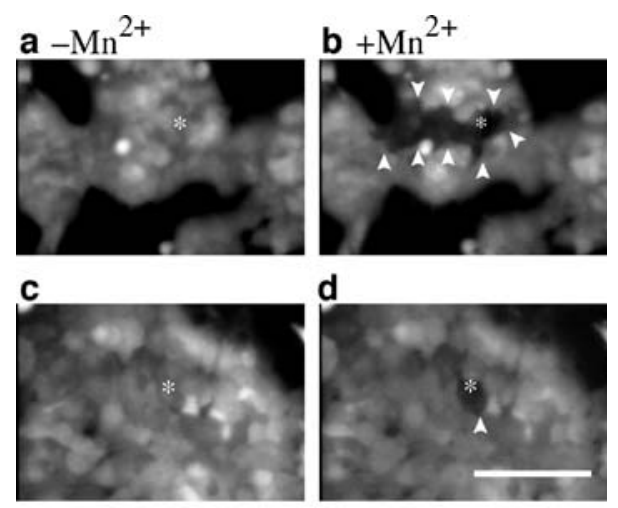

e

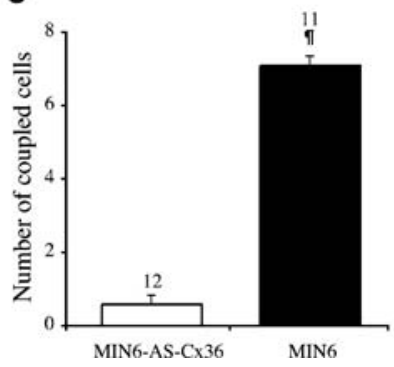

Fig. 6 MIN6 cells exchange $\mathrm{Mn}^{2+}$ in a similar way to larger cationic tracers. a, b Cultures of wild-type MIN6 cells were loaded with calcein-AM, before individual cells were microinjected with $\mathrm{Mn}^{2+}$. This ion induced the quenching of calcein fluorescence in the microinjected cell (asterisk) and then in all neighbours coupled to it (arrow heads). c, d In MIN6-AS-Cx36 cells, which express little Cx36, diffusion of the $\mathrm{Mn}^{2+}$-induced fluorescence quenching was observed in no more than one coupled cell (arrowhead). Bar, $100 \mu \mathrm{m}$. e Number of wild-type (solid bar, 11 microinjections) and Cx36antisense cells (open bar, 12 microinjections) featuring a quenching of calcein fluorescence after microinjection of $\mathrm{Mn}^{2+}$ into one cell. Data are presented as means \pm SEM. ${ }^{\AA} p<0.0005$ vs the value in $\mathrm{Cx} 36$ antisense cells

observed for PI and EB (compare Figs. 5c and 6e), two molecules significantly larger than the quenching-inducing $\mathrm{Mn}^{2+}$. MIN6 cells that had been transfected for an antisense Cx36 cDNA failed to show $\mathrm{Mn}^{2+}$-induced quenching outside the microinjected cell (Fig. 6c-e). These findings show that a comparable coupling of insulin-producing cells is revealed by cationic tracers of rather different size and is dependent on the presence of Cx36 channels.

\section{Discussion}

In pancreatic islets, beta cells are linked by $\mathrm{Cx} 36$ channels $[14,20,24,25]$, which account for electrical coupling [5, 7, $10,13,15,22,23]$, as well as for the intercellular synchronisation of glucose-induced electrical activity [5, $10,15,22]$ and $\mathrm{Ca}^{2+}$ transients $[15,21,23,35]$. The same channels also allow beta cells to exchange cytosolic molecules $[11,15,23]$ and exogenous tracers $[8,12,17-$ 19, 21, 29]. Previous studies have shown that blockade or loss of $\mathrm{Cx} 36$ leads to altered function of beta cells, notably with regard to basal and glucose-stimulated insulin secretion [19, 21, 27, 35, 43]. Alterations in insulin secretion have also been reported following either the overexpression of Cx36 [39, 43] or the forced expression in beta cells of a connexin that is not natively expressed in the islets [17]. Together, these data imply a central role of beta cell coupling in the regulation of islet function and indicate that connexin-dependent signalling specifically requires $\mathrm{Cx} 36$.

Why this protein, which is only expressed in the nervous and endocrine systems [20], is essential for beta cells remains to be determined. Compared with the other 20 known connexins [4, 20], Cx36 confers upon homomeric channels a rather low voltage sensitivity, a small unitary conductance and a differential permeability to $L Y$ and neurobiotin $[4,30,31$, 39]. It typically forms gap junctions comprising only a few dozen connexons [37, 38, 42]. The minimal voltage sensitivity is advantageous to beta cells since it allows Cx36 channels to remain open under both basal and stimulated conditions. The modest number of low-conductance channels allows the finetuning of communication between beta cells, which have a high input resistance $[5,7,10,14,22,23]$. The differential permeability of $\mathrm{Cx} 36$ to molecules that have the size of endogenous metabolites and second messengers could explain the variable estimations of beta cell coupling so far reported. Thus, whereas electrophysiological data and $\mathrm{Ca}^{2+}$ measurements have indicated that ionic coupling may extend throughout entire islets [5, 7, 21, 22, 29, 44, 45], experiments evaluating the intercellular exchange of endogenous metabolites or exogenous tracers have indicated a more restricted coupling $[8,11,12,15,17-19,21,23,29]$. However, the comparison of these findings is complicated, since previous studies have evaluated islet cell coupling with different techniques [28, 29], tested junctional conductance indirectly $[5,7,10,22]$ and/or studied beta cells in a non-physiological environment $[5,8,10,11,15,22,45]$. Thus, the question of what is transferred between beta cells via the Cx36 channels of intact islets remains to be established.

To address these issues, we used novel animal models that allow unambiguous control of various connexins and analysis of coupling within the normal islet environment. Using a series of gap junction tracers selected for subtle differences in molecular weight and electrical charge, we showed that $\mathrm{C} \times 36$ channels favour the exchange between beta cells of selected cationic molecules, restraining that of anionic molecules. We showed that this exchange is drastically modified when beta cells are forced to express Cx32, a connexin that is not natively found in islets $[14,20$, 24, 25] and forms channels preferentially permeated by anionic molecules [4, 17, 33, 39]. Using a fluorescence quenching approach, we extended to $\mathrm{Mn}^{2+}$ the previous evidence that $\mathrm{Cx} 36$ channels are also permeated by currentcarrying cations $[21,22,26,35,44,45]$ and showed that the extent of this ionic coupling is similar to that observed with 
much larger cationic molecules. By comparing normal and $\mathrm{KO}$ mice lacking $\mathrm{Cx} 36$, as well as wild-type and $\mathrm{Cx} 36-$ antisense-transfected MIN6 cells, our data conclusively show that $\mathrm{Cx} 36$ is both necessary and sufficient to ensure the native, selective coupling of beta cells. Our data also indicate that $\mathrm{Cx} 36$ channels are not identical in insulin-producing cells and HeLa cells (e.g. the permeability to EB is similar in the two cell types, whereas that to PI is not), supporting the view that a cell-specific environment modulates their function [13, 23], as suggested for other connexin isoforms $[46,47]$. While the underlying mechanism remains to be elucidated, plausible reasons are the interactions of connexins with different proteins/lipids and/or a different regulation by cell-specific post-translational processes. In this respect, current evidence indicates that the level of Cx36 phosphorylation may vary in different cell types $[13,32]$. Our data also show that after in vivo stimulation with sulfonylurea $[12,37,38]$, beta cell coupling is enhanced. Together with the previous report that the same treatment enlarges islet gap junctions [37, 38], these findings indicate that increased number/function of $\mathrm{Cx} 36$ channels is required during stimulation of insulin secretion, possibly to recruit increasing numbers of secreting cells $[14,16,19,20]$. Strikingly, the intercellular exchange of cationic and anionic molecules was not modified to the same extent, indicating that a subtle modulation of the resting Cx36 permselectivity occurs during stimulation of insulin secretion.

These data have three implications. First, they suggest that cationic molecules may be the main messengers of connexin signalling between beta cells. This knowledge should facilitate the identification of these factors, in as far as most endogenous metabolites are negatively charged at cytosolic $\mathrm{pH}[4,11,23]$. Second, our experiments indicate that the ionic and molecular coupling of beta cells may not be as different as previously thought $[5,7,8,10,11,15,23,29]$. The new data show that the extent of coupling provided by $\mathrm{C} \times 36$ channels is sufficient to involve sizable proportions of, though not all beta cells of an islet. Moreover, under all the conditions we tested, a number of beta cells appeared to be uncoupled from their neighbours, which is consistent with the previously reported distribution of gap junctions, the estimated number of functional junctional channels and their average open time probability $[4,6,48]$. Third, our experiments demonstrate that $\mathrm{Cx} 36$ is the only connexin that functionally couples pancreatic beta cells [21, 22, 24, 25], with specific deletion of this protein abolishing the intercellular exchange of the five probes we tested. These data extend recent freeze-fracture, dye injection and electrophysiological observations [21, 22], indicating that if other connexins are expressed in beta cells $[49,50]$, these proteins do not form functional cell-to-cell channels.

In summary, our data show that within pancreatic islets, beta cells featuring Cx36 channels extensively exchange positively charged molecules of various size and exchange negatively charged molecules to a much smaller degree. The identification of such an extensive coupling resolves the longstanding controversy regarding a purported difference between the extent of electrical and metabolic coupling of islet cells. Our data show that large numbers of beta cells, although not all of them, are coupled within primary islets. We also definitively show that this coupling is uniquely due to $\mathrm{Cx} 36$ channels. The identification of a permselectivity of the $\mathrm{Cx} 36$ channels is expected to facilitate the identification of the endogenous molecules that are exchanged between beta cells. Our findings also document that the beta cell exchanges of anionic and cationic molecules are differentially regulated during in vivo stimulation of insulin secretion. This finding opens new perspectives for the unravelling of the mechanism whereby Cx36 signalling contributes to the proper control of insulin biosynthesis and release.

Acknowledgements The authors thank A. Charollais, D. Caille and I. Borges for valuable assistance. The work of our team is supported by grants from the Swiss National Science Foundation (310000109402), the Juvenile Diabetes Research Foundation (1-2005-46 and 1-2007-158), Novo Nordisk and the Geneva Program for Metabolic Disorders.

Duality of interest The authors declare that there is no duality of interest associated with this manuscript.

\section{References}

1. Ashcroft FM, Gribble FM (1999) ATP-sensitive $\mathrm{K}^{+}$channels and insulin secretion: their role in health and disease. Diabetologia 42:903-919

2. MacDonald PE, Joseph JW, Rorsman P (2005) Glucose-sensing mechanisms in pancreatic beta-cells. Philos Trans R Soc Lond B Biol Sci 360:2211-2225

3. Rorsman P (1997) The pancreatic beta-cell as a fuel sensor: an electrophysiologist's viewpoint. Diabetologia 40:487-495

4. Harris AL (2001) Emerging issues of connexin channels: biophysics fills the gap. Q Rev Biophys 34:325-472

5. Kanno T, Gopel SO, Rorsman P, Wakui M (2002) Cellular function in multicellular system for hormone-secretion: electrophysiological aspect of studies on alpha-, beta- and delta-cells of the pancreatic islet. Neurosci Res 42:79-90

6. Verselis VK, Veenstra R (2000) Gap junction channels, permeability and voltage gating. Adv Mol Cell Biol 30:129-192

7. Andreu E, Soria B, Sanchez-Andres JV (1997) Oscillation of gap junction electrical coupling in the mouse pancreatic islets of Langerhans. J Physiol 498:753-761

8. Kohen E, Kohen C, Thorell B, Mintz DH, Rabinovitch A (1979) Intercellular communication in pancreatic islet monolayer cultures: a microfluorometric study. Science 204:862-865

9. MacDonald PE, Rorsman P (2006) Oscillations, intercellular coupling, and insulin secretion in pancreatic beta cells. PLoS Biol 4:e49

10. Mears D, Sheppard NFJ, Atwater I, Rojas E (1995) Magnitude and modulation of pancreatic beta-cell gap junction electrical conductance in situ. J Membr Biol 146:163-176 
11. Meda P, Amherdt M, Perrelet A, Orci L (1981) Metabolic coupling between cultured pancreatic b-cells. Exp Cell Res 133:421-430

12. Meda P, Michaels RL, Halban PA, Orci L, Sheridan JD (1983) In vivo modulation of gap junctions and dye coupling between B-cells of the intact pancreatic islet. Diabetes 32:858-868

13. Moreno AP, Berthoud VM, Perez-Palacios G, Perez-Armendariz EM (2005) Biophysical evidence that connexin-36 forms functional gap junction channels between pancreatic mouse beta-cells. Am J Physiol Endocrinol Metab 288:E948-E956

14. Nlend RN, Michon L, Bavamian S et al (2006) Connexin36 and pancreatic beta-cell functions. Arch Physiol Biochem 112:74-81

15. Pedersen MG, Bertram R, Sherman A (2005) Intra- and inter-islet synchronization of metabolically driven insulin secretion. Biophys $\mathbf{J}$ 89:107-119

16. Bosco D, Meda P (1997) Reconstructing islet function in vitro. Adv Exp Med Biol 426:285-298

17. Charollais A, Gjinovci A, Huarte J et al (2000) Junctional communication of pancreatic beta cells contributes to the control of insulin secretion and glucose tolerance. J Clin Invest 106:235-243

18. Kohen E, Kohen C, Rabinovitch A (1983) Cell-to-cell communication in rat pancreatic islet monolayer cultures is modulated by agents affecting islet-cell secretory activity. Diabetes 32:95-98

19. Meda P, Bosco D, Chanson M et al (1990) Rapid and reversible secretion changes during uncoupling of rat insulin-producing cells. J Clin Invest 86:759-768

20. Michon L, Nlend Nlend R, Bavamian S et al (2005) Involvement of gap junctional communication in secretion. Biochim Biophys Acta 1719:82-101

21. Ravier MA, Guldenagel M, Charollais A et al (2005) Loss of connexin 36 channels alters beta-cell coupling, islet synchronization of glucose-induced $\mathrm{Ca}^{2+}$ and insulin oscillations, and basal insulin release. Diabetes 54:1798-1807

22. Speier S, Gjinovci A, Charollais A, Meda P, Rupnik M (2007) Cx36-mediated coupling reduces beta-cell heterogeneity, confines the stimulating glucose concentration range, and affects insulin release kinetics. Diabetes 56:1078-1086

23. Tsaneva-Atanasova K, Zimliki CL, Bertram R, Sherman A (2006) Diffusion of calcium and metabolites in pancreatic islets: killing oscillations with a pitchfork. Biophys J 90:3434-3446

24. Serre-Beinier V, Le Gurun S, Belluardo N et al (2000) Cx36 preferentially connects beta-cells within pancreatic islets. Diabetes 49:727-734

25. Theis M, Mas C, Doring B et al (2004) Replacement by a lacZ reporter gene assigns mouse connexin36, 45 and 43 to distinct cell types in pancreatic islets. Exp Cell Res 294:18-29

26. Calabrese A, Caton D, Meda P (2004) Differentiating the effects of $\mathrm{Cx} 36$ and E-cadherin for proper insulin secretion of MIN6 cells. Exp Cell Res 294:379-391

27. Konstantinova I, Nikolova G, Ohara-Imaizumi M et al (2007) EphA-ephrin-A mediated beta cell communication regulates insulin secretion from pancreatic islets. Cell 129:359-370

28. Meda P (2000) Probing the function of connexin channels in primary tissues. Methods 20:232-244

29. Quesada I, Fuentes E, Andreu E, Meda P, Nadal A, Soria B (2003) On-line analysis of gap junctions reveals more efficient electrical than dye coupling between islet cells. Am J Physiol Endocrinol Metab 284:E980-E987

30. Srinivas M, Rozental R, Kojima T et al (1999) Functional properties of channels formed by the neuronal gap junction protein connexin36. J Neurosci 19:9848-9855
31. Teubner B, Degen J, Sohl G et al (2000) Functional expression of the murine connexin 36 gene coding for a neuron-specific gap junctional protein. J Membr Biol 176:249-262

32. Urschel S, Hoher T, Schubert T et al (2006) Protein kinase Amediated phosphorylation of connexin36 in mouse retina results in decreased gap junctional communication between AII amacrine cells. J Biol Chem 281:33163-33171

33. Elfgang C, Eckert R, Lichtenberg-Frate H et al (1995) Specific permeability and selective formation of gap junction channels in connexin-transfected HeLa cells. J Cell Biol 129: 805-817

34. Miyazaki J, Araki K, Yamato E et al (1990) Establishment of a pancreatic beta cell line that retains glucose-inducible insulin secretion: special reference to expression of glucose transporter isoforms. Endocrinology 127:126-132

35. Calabrese A, Zhang M, Serre-Beinier V et al (2003) Connexin 36 controls synchronization of $\mathrm{Ca}^{2+}$ oscillations and insulin secretion in MIN6 cells. Diabetes 52:417-424

36. Guldenagel M, Ammermuller J, Feigenspan A et al (2001) Visual transmission deficits in mice with targeted disruption of the gap junction gene connexin36. J Neurosci 21:6036-6044

37. Meda P, Halban P, Perrelet A, Renold AE, Orci L (1980) Gap junction development is correlated with insulin content in the pancreatic B cell. Science 209:1026-1028

38. Meda P, Perrelet A, Orci L (1979) Increase of gap junctions between pancreatic B-cells during stimulation of insulin secretion. J Cell Biol 82:441-448

39. Caton D, Calabrese A, Mas C et al (2003) Lentivirus-mediated transduction of connexin cDNAs shows level- and isoform-specific alterations in insulin secretion of primary pancreatic beta-cells. J Cell Sci 116:2285-2294

40. Sawahara H, Goto S, Kinoshita N (1991) Double fluorescent labeling method used for a study on liposomes. Chem Pharm Bull (Tokyo) 39:227-229

41. Meda P, Santos RM, Atwater I (1986) Direct identification of electrophysiologically monitored cells within intact mouse islets of Langerhans. Diabetes 35:232-236

42. Abramoff MD, Magelhaes PJ, Ram SJ (2004) Image processing with ImageJ. Biophoton Int 11:36-42

43. Le Gurun S, Martin D, Formenton A et al (2003) Connexin-36 contributes to control function of insulin-producing cells. J Biol Chem 278:37690-37697

44. Meda P, Atwater I, Goncalves A, Bangham A, Orci L, Rojas E (1984) The topography of electrical synchrony among beta-cells in the mouse islet of Langerhans. Q J Exp Physiol 69:719-735

45. Meissner HP (1976) Electrophysiological evidence for coupling between beta cells of pancreatic islets. Nature 262:502-504

46. Eckert R (2006) Gap-junctional single-channel permeability for fluorescent tracers in mammalian cell cultures. Biophys J 91:565-579

47. Koval M (2006) Pathways and control of connexin oligomerization. Trends Cell Biol 16:159-166

48. Perez-Armendariz M, Roy C, Spray DC, Bennett MV (1991) Biophysical properties of gap junctions between freshly dispersed pairs of mouse pancreatic beta cells. Biophys J 59:76-92

49. Collares-Buzato CB, Leite AR, Boschero AC (2001) Modulation of gap and adherens junctional proteins in cultured neonatal pancreatic islets. Pancreas 23:177-185

50. Leite AR, Carvalho CP, Furtado AG, Barbosa HC, Boschero AC, Collares-Buzato CB (2005) Co-expression and regulation of connexins 36 and 43 in cultured neonatal rat pancreatic islets. Can J Physiol Pharmacol 83:142-151 